\title{
Sprawozdanie
}

\section{Międzynarodowa Konferencja Naukowa nt.: Efektywność europejskiego systemu ochrony Praw Człowieka, Warszawa, 18-19 kwietnia 2011 r.}

W dniach 18-19 kwietnia 2011 r. odbyła się w Sejmie RP Międzynarodowa Konferencja Naukowa Efektywność europejskiego systemu ochrony praw człowieka. Była to trzecia $\mathrm{z}$ serii międzynarodowych konferencji, poświęconych kluczowym problemom rozwoju demokracji w Europie. Poprzednie zatytułowane były: Europa jako obszar demokracji, praworzadności i ochrony praw człowieka. Rada Europy na przemiany demokratyczne w państwach Europy Środkowej i Wschodniej w latach 1989-2009 (Szklarska Poręba 2009) ${ }^{1}$ i Transformacja systemów wymiaru sprawiedliwości w państwach Europy Środkowej $i$ Wschodniej w latach 1989-2009 (Legnica 2010)2.

Organizatorami tegorocznej konferencji byli: Instytut Ekonomii i Administracji Uniwersytetu Humanistyczno-Przyrodniczego Jana Kochanowskiego w Kielcach oraz Komisja Sprawiedliwości i Praw Człowieka Sejmu RP. W organizacji konferencji brały też udział: Centrum Badawcze OPF, Fundacja Promocji Prawa Europejskiego, Fundacja Praw Podstawowych oraz Międzynarodowe Centrum Prawa i Zarządzania WSM w Legnicy.

Konferencja miała tym bardziej doniosłe znaczenie, że zorganizowana została z okazji 20-lecia akcesji Polski do Rady Europy i podpisania Europejskiej Konwencji Praw Człowieka. Patronat honorowy objął nad nią sekretarz generalny Rady Europy, T. Jagland. Słowa powitalne skierowała do uczestników konferencji rektor UJK, prof. dr hab. R. Renz. W ceremonii powitania wzięli udział, m.in. wicemarszałek Sejmu prof. S. Niesiołowski, prezes Trybunału Konstytucyjnego, prof. A. Rzepliński, minister sprawiedliwości, K. Kwiatkowski oraz stały przedstawiciel RP przy Radzie Europy, amb. U. Gacek. Przesłania do uczestników konferencji skierowali: Prezydent RP, B. Komorowski oraz sekretarz generalny Rady Europy, T. Jagland.

1 Zob.: Rada Europy a przemiany demokratyczne w Europie Środkowej i Wschodniej w latach 1989-2009), pod red. J. Jaskierni, Toruń 2010.

2 Zob.: Transformacja systemów wymiaru sprawiedliwości, t. I i II, pod red. J. Jaskierni, Toruń 2011. 
Głównym przedmiotem dyskusji podczas konferencji był szeroko pojęty system ochrony praw człowieka, jego rozwój oraz poprawa efektywności. Debata dotycząca tego systemu trwa od lat i owocuje zmianami. Przyjęcie Deklaracji Konferencji państw członkowskich w Interlaken oraz towarzyszącego jej Planu Działania zapoczątkuje kolejne reformy. Obydwa dokumenty będą stanowily wyraz zgodnej decyzji politycznej o potrzebie reform oraz wskazują na możliwe kierunki zmian w perspektywie krótko-, średnioi długofalowej. W ramach przygotowań do Interlaken rozważane były różne warianty reformy systemu ochrony praw człowieka. Minister sprawiedliwości K. Kwiatkowski podczas swojego wystąpienia przedstawił stanowisko rządu dotyczące reformy mechanizmu konwencyjnego, opierające się na trzech podstawowych filarach. Pierwszy z nich to utrzymanie instytucji skargi indywidualnej w nienaruszonym zakresie jako istoty całego systemu. Polskie stanowisko wykluczało poparcie dla „mechanicznych” sposobów ograniczania liczby skarg (takich jak wprowadzenie opłat), a rozwiązania takie miały licznych zwolenników. To stanowisko nie uległo zmianie, konsekwentnie sprzeciwiamy się opłatom, warunkującym dopuszczalność skargi - mówił minister K. Kwiatkowski. - Podobnie negatywne stanowisko zajmujemy np. wobec pojawiających się sugestii nałożenia obowiązku sporządzenia skargi w językach urzędowych - dodał. Drugi z filarów to dalsze rozwinięcie zasady subsydiarności. Polska przedstawiła koncepcję stanowiącą wartość dodaną do art. 13 Konwencji i zaproponowała Radzie Europy rozpoczęcie dyskusji na temat warunków uznania za środek efektywny tzw. „krajowego środka o charakterze generalnym". Trzeci z filarów to uelastycznienie mechanizmu dokonywania zmian proceduralnych i organizacyjnych Trybunału. Dotychczasowe doświadczenie z reformowaniem systemu poprzez zmiany Konwencji i przyjmowanie kolejnych protokołów uczy, że jest to proces trudny i długotrwały - mówił podczas konferencji minister sprawiedliwości.

Obrady toczyły się w czterech sesjach plenarnych oraz w ośmiu panelach dyskusyjnych.

Pierwszej sesji plenarnej Rozwój systemu ochrony praw człowieka przewodniczył prof. W. Sokolewicz (Akademia Leona Koźmińskiego w Warszawie). Zaprezentowane zostały następujące referaty: prof. H. Schambeck (University of Linz), The idea of man and human rights in present; prof. G. Grabowska (Uniwersytet Śląski w Katowicach), Prawa człowieka u progu XXI wieku. Rozwój i kierunki zmian; prof. J. Oniszczuk (Szkoła Główna 
Handlowa w Warszawie), Równowaga i równość $w$ sferze ochrony wolności i praw człowieka; prof. K. Klima (University of West Bohemia, Pilsen, Czechy), Efficiency of the Relationship between Constitutional Law and European Human Rights Law; prof. J. Kolarzowski (Uniwersytet Warszawski), Prawa socjalne - prawami człowieka. Różnorodność i perspektywy unifikacji; prof. Z. Lasocik (Uczelnia Łazarskiego w Warszawie), Zakaz tortur - standard, inny wymiar i nowe wyzwania; prof. M. Doroshenko (Narodowy Uniwersytet Ukrainy, Kijów, Ukraina), Значение Хартии ЕС об основных правах 2000 года для бормирования механизма защиты прав и свобод человека в Европейском Союзе.

Drugiej sesji plenarnej, Uwarunkowania efektywności europejskiego system ochrony praw człowieka, przewodniczył prof. M. Zubik (Uniwersytet Warszawski). Wysłuchano następujących referatów: prof. L. Garlicki (Uniwersytet Warszawski), Kryteria oceny efektywności europejskiego systemu ochrony praw człowieka; prof. J. Jaskiernia (Uniwersytet Humanistyczno Przyrodnyczy Jana Kochanowskiego w Kielcach), Rada Europy, Unia Europejska $i$ OBWE w europejskim systemie ochrony praw człowieka - synergia działań czy konkurencja?; dr P. Świtalski (ambasador tytularny, Dyrektor ds. planowania politycznego, Sekretariat Generalny Rady Europy, Strasburg, Francja), Europejski system ochrony praw człowieka: OBWE a Rada Europy na tle zmian w środowisku politycznym Europy; amb. J. W. Bertens (European Parliament Former Members Association, Holandia), Human Rights in the European Union; prof. S. Kaźmierczyk (Uniwersytet Wrocławski, Wyższa Szkoła Menedżerska w Legnicy), Wykonywanie Europy i praw człowieka przez Unię Europejska; prof. N. Chronowski (Uniwersytet w Pecu, Węgry), Integration of European Human Rights Standards - the Accession of EU to the ECHR; prof. A. Wróbel (Instytut Nauk Prawnych PAN, sędzia Sądu Najwyższego), Ochrona tymczasowa w orzecznictwie Europejskiego Trybunału Praw Człowieka; prof. A. Bisztyga (Uniwersytet Śląski w Katowicach), Wątki islamskie w orzecznictwie Europejskiego Trybunału Praw Człowieka.

Trzeciej sesji plenarnej, Przesłanki skuteczności europejskiego systemu ochrony praw człowieka, przewodniczył prof. B. Szmulik (Uniwersytet Kardynała Stefana Wyszyńskiego w Warszawie). Zaprezentowane zostały następujące referaty: prof. J. Menkes (Wyższa Szkoła Psychologii Społecznej w Warszawie), Funkcjonariusz versus organizacja międzynarodowa - prawa podstawowe versus immunitet jurysdykcyjny; prof. J. Svak, Dr B. Balog 
(Pan European University, Bratislava, Słowacja), Trends in the judicature of European Court of Human Rights and the execution of judgments of European Court of Human Rights in Slovakia; prof. K. Drzewicki (Uniwersytet Gdański), The Modalities of Simplified Procedures for Amending the European Convention on Human Rights; doc. A. Waszkiewicz (Białoruski Uniwersytet Państwowy, Mińsk, Białoruś), Spontaneous assemblies in the decisions of the ECHR and in the national legislation; dr R. Wiewiórowski (Uniwersytet Gdański), Przyszłość Konwencji 108 Rady Europy jako podstawy europejskiego systemu ochrony prywatności; prof. I. Aliebastrova (Moskiewska Państwowa Akademia Prawa, Moskwa, Federacja Rosyjska), The Natural Law Conception of Human Rights in European and Russian Law; prof. K. Karski (Uniwersytet Warszawski), Instytucjonalne gwarancje niezależności sędziów Europejskiego Trybunału Praw Człowieka jako czynnik wpływajacy na efektywność europejskiego systemu ochrony praw człowieka; dr T. L’alík (Comenius University, Bratislava, Słowacja), Understanding the Binding Effect of the Case-Law of the ECtHR in Domestic Legal Order; dr A. Bodnar (Uniwersytet Warszawski): Zasada subsydiarności a implementacja wyroków Europejskiego Trybunału Praw Człowieka dotyczących państw trzecich; M. Kononenko (doradca ministra, Ministerstwo Spraw Zagranicznych Ukrainy, Kijów, Ukraina), Институциональный механизм защциты прав и свобод человека в Европейском Союзе.

Czwartej sesji plenarnej - Uwarunkowania rozwoju systemu ochrony praw człowieka, przewodniczył prof. M. Mazurkiewicz (przewodniczący Rady Programowej Międzynarodowego Centrum Prawa i Zarządzania WSM w Legnicy). W trakcie tej sesji wysłuchano następujących referatów: prof. J. Maciejewski (Uniwersytet Wrocławski), Trans-europejski wymiar makro-systemu grup dyspozycyjnych w społeczeństwie obywatelskim; prof. J. Sobczak (Szkoła Wyższa Psychologii Społecznej, sędzia Sądu Najwyższego), dr W. Sobczak (Uniwersytet Adama Mickiewicza, Poznańskie Centrum Praw Człowieka Instytutu Nauk Prawnych PAN), Wolność sumienia $i$ wyznania - prawo człowieka czy iluzja?; ks. prof. J. Kułaczkowski (Uniwersytet Kardynała Stefana Wyszyńskiego w Warszawie), Znaczenie nauczania Kościoła o prawach rodziny dla kultury europejskiej; prof. B. Wojciechowski (Uniwersytet Łódzki), Między relatywizmem a uniwersalizmem praw człowieka we wspótczesnej filozofii prawa; dr R. Grzeszczak (Uniwersytet Warszawski), Ochrona praw jednostki w Unii Europejskiej przez zasadę dobrej administra- 
cji; prof. E. Weiss (Wyższa Szkoła Finansów i Zarządzania w Warszawie), System ochrony prawnej praw jednostki w procesie aplikowania o środki unijne. prof. Сауле Кошкеновна Амандыкова (Karagandijskij Gosudarstwiennyj Uniwiersitiet im. J.A. Bukietowa, Karaganda, Kazachstan), Развитие концепиии прав человека в Конституции Республики Казахстан 1995 года.

Ważny plon naukowy przyniosło także osiem paneli dyskusyjnych, poświęconych poszczególnym zagadnieniom europejskiego systemu ochrony praw człowieka. Zaprezentowało się w nich m.in. kilkudziesięciu młodych naukowców.

Jak powiedział prof. M. Mazurkiewicz, podsumowując konferencję, zgłoszone i wygłoszone ponad 140 referatów dotyczyło najbardziej ważkich we współczesnym świecie kwestii czyli przestrzegania praw człowieka i obywatela, praw każdego z nas. Konferencja będzie więc miała istotne znaczenie nie tylko dla teorii, ale też dla praktyki życia politycznego.

Organizator konferencji, prof. J. Jaskiernia podkreślił, że była to konferencja pluralistyczna, eksponująca różne podejścia ideologiczne i światopoglądowe do problematyki praw człowieka. Przedstawiały na niej swoje poglądy osoby reprezentujące zarówno dojrzałe demokracje, jak i kraje, w których system demokratyczny dopiero się kształtuje.

Wszystkie referaty, jakie zostały zaprezentowane w trakcie konferencji, zarówno podczas obrad plenarnych, jak i w panelach, zostaną opublikowane w monografii, staraniem Wydawnictwa Adam Marszałek w Toruniu.

Tradycja międzynarodowych konferencji naukowych, koordynowanych przez prof. J. Jaskiernię, będzie kontynuowana. Wnoszą one nie tylko istotny wkład do rozwoju nauki, ale też praktyki ustrojowej. Dają szansę zaprezentowania się zarówno wybitnym uczonym, ale także młodym naukowcom.

Kamil Spryszak (Uniwersytet Humanistyczno-Przyrodniczy Jana Kochanowskiego w Kielcach) 